\title{
Salmonella Serotype Choleraesuis
}

National Cancer Institute

\section{Source}

National Cancer Institute. Salmonella Serotype Choleraesuis. NCI Thesaurus. Code C86915.

Any bacterial organism that can be assigned to the genus Salmonella with serotype Choleraesuis. 